\title{
Role of trpv1 (transient receptor potential v1 channel) in piperine induced hyperalgesia: a preliminary study
}

\author{
Priyanshee Gohil *, Chhaya Patel, Gaurang Shah \\ Department of Pharmacology and Clinical Pharmacy, K.B. Institute of Pharmaceutical Education and Research, \\ Kadi Sarvavishvawidyalaya, Gandhinagar, Gujarat, India \\ *Corresponding author E-mail: priyansheeg@yahoo.co.in
}

\begin{abstract}
Background: The inflammatory disease is associated with chronic pain and hypersensitivity to noxious stimuli in form of hyperalgesia. Transient receptor potential vanilloid type-1 (TRPV1) activated by various inflammatory mediators; plays a key role in occurrence of hyperalgesia. Piperine is the primary pungent alkaloid of Piper nigrum. Piperine has common binding site with capsaicin (TRPV1 agonist) on TRPV1 and it has more efficacy for activation of TRPV1 than capsaicin.

Objective: The purpose of the study was to investigate the role of TRPV1 in piperine induced hyperalgesia in diabetic mice.

Methods: Diabetes mellitus was induced in mice using streptozotocin (STZ). Nociception was measured by three types of thermal nociceptive tests (Hot plate method, radient heat tail-flick method and tail immersion test). Pilot study (using 2.5, 5, 10 and $50 \mathrm{mg} \mathrm{kg}-1$ piperine, i.p.) was carried out and $5 \mathrm{mg} \mathrm{kg}-1$ piperine is used as optimum dose for further study. Capsaicin, capsazepine and piperine were administered to their respected groups and nociceptive threshold was noted on day 4, 7 and 10 in all groups.

Results: Piperine showed a significant decrease in nociceptive threshold as compared to diabetic control group, while there was a significant increase in reaction time, tail flick latency and tail withdrawal latency, in the animals pre-treated with capsazepine before piperine administration as compare to only piperine treated diabetic group.

Conclusion: Activation of TRPV1 might be one of the possible mechanisms of Piperine induced hyperalgesia.
\end{abstract}

Keywords: Capsaicin, Capsazepine, Hyperalgesia, Nociceptive Threshold, Piperine, TRPV1.

\section{Introduction}

Piperine (1-peperoylpiperidine) (Fig. 1), the primary pungent alkaloid responsible for pungency of black pepper and long pepper derived from Piper nigrum. It commonly used as bioavaibility enhancer (McNamara et al. 2005). The burning sensation of piperine is through activation of the heat and capsaicin receptor i.e. transient receptor potential V1 channel (TRPV1) (Szolcsanyi 1983, Patacchini et al. 1990). TRPV1 is the ion channels of TRP family to be identified at molecular level (Caterina 1997). Some study demonstrated that piperine has common binding site with capsaicin (TRPV1 agonist) on vanilloid receptors expressed in native tissue (Szallasi \& Blumberg 1999). Recently, Martin Gunthorpe and co-workers demonstrated that piperine has more efficacies for activation of TRPV1 than capsaicin (Fig. 2) (McNamara et al. 2005).

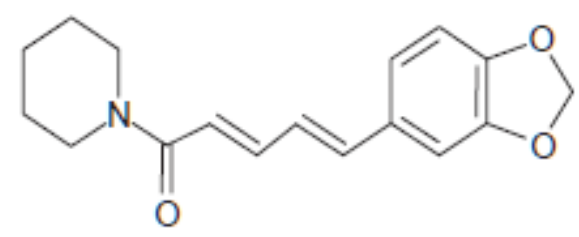

Fig. 1: Chemical Structure of Piperine<smiles>COc1cc(CNC(=O)CCCC/C=C/C(C)C)ccc1O</smiles>

Fig. 2: Chemical Structure of Capsaicin

The TRPV1 previously known as the vanilloid receptor 1 (VR1), is a non-selective cation channel plays a critical role in inflammatory pain states by mediating sensory neuron activation by chemical and thermal stimuli (Szolcsanyi 1983, Caterina et al. 2000, Davis et al. 2000, Voets et al. 2004) and factors released during inflammation sensitize TRPV1 to enhance hyperalgesia (Cesare et al. 1999, Pingle et al. 2007). Hyperalgesia is defined as an increased responsiveness to a noxious stimulus and can be due to sensitization of the peripheral endings of nerve fibers, such that they respond to a given thermal or mechanical stimulus with many more action potentials, resulting in increased stimulation of dorsal horn neurons.

Diabetic patients frequently exhibit increased responsiveness to noxious stimuli (hyperalgesia) and hyper- responsiveness to normaly innocuous stimuli (allodynia) that are often concurrent with a paradoxical loss stimulus evoked sensation (Spruce et al. 2003). Similar to human diabetic pain, animal model such as streptozotocin (STZ) induced diabetic neuropathy also demonstrates thermal hyperalgesia and mechanical allodynia (Spruce et al. 2003). In experimental diabetic neuropathy, the development of 
hyperalgesia is due to increased expression of TRPV 1 on neurons that do not normally express TRPV1 (Rashid et al. 2003a, Hudson et al. 2001)

Therefore the present study was designed to investigate the role of TRPV1 in piperine induced hyperalgesia in diabetic mice.

\section{Methods}

\subsection{Animals}

Healthy albino mice of either sex, weighing 25-30 g were procured from Zydus Research Centre, India. The animals were housed and maintained at $298 \mathrm{~K}, 50 \pm 15 \% \mathrm{RH}$ for 12 hour lightdark cycles, in polypropylene cages with free access to food and water ad libitum. The experimental protocol (KBIPER/2011/248) was approved by the Institutional (K. B. Institute of Pharmaceutical Education and Research) Animal Ethics Committee (IAEC) under the Committee for the Purpose of Control and Supervision of Experiments on Animals (CPCSEA) guideline, before carrying out the project.

\subsection{Chemicals}

Streptozotocin, piperine and capsaicin were obtained from SigmaAldrich, USA while capsazepine obtained from Cayman chemical, China. Dimethylsulphoxide (DMSO) was purchased from Sujan Chemials, India.

Piperine was dissolved in saline. Capsaicin and capsazepine was dissoved in $30 \%$ DMSO to prepare stock solution and it was diluted further in saline to prepare working solutions.

\subsection{Experimental design}

\subsubsection{Induction of diabetes in mice}

Diabetes mellitus was induced in mice using STZ. Streptozotocin was freshly prepared by dissolving $1 \mathrm{~g} \mathrm{STZ}$ in $10 \mathrm{ml} 0.1 \mathrm{~N}$ cold citrate buffer $(1.45 \mathrm{~g}$ citric acid and $1.05 \mathrm{~g}$ sodium citrate dissolved in $100 \mathrm{ml}$ distilled water) at a $\mathrm{pH}$ of 4.5. Single dose of STZ (30 $\mathrm{mg} \mathrm{kg}^{-1}$, i.p.) was administration for induction of diabetes and $10 \% \mathrm{~W} / \mathrm{V}$ oral glucose was given to all animals after $6 \mathrm{~h}$ of STZ administration to prevent the hypoglycemic shock. Control animals received an equivalent volume of saline. Confirmation of hyperglycemia was made 3 days later by measurement of the fasting blood glucose (FBG) level. Mice with FBG level $>200 \mathrm{mg} / \mathrm{dl}$ were considered diabetic and were included for further study (Chakir \& Plante 1996, Rashid et al. 2003b).

Estimation of blood glucose

Blood glucose levels were estimated spectrophotometrically by glucose-oxidase method using a commercially available enzymatic kit (Span Diagnostics Ltd., India) (Trinder 1996).

\subsubsection{Measurement of nociceptive response}

Nociception was measured by three types of thermal nociceptive tests (Hot plate method, radient heat tail-flick method and tail immersion test).

\section{- Hot plate method:}

The mice were placed individually on a hot plate (Max enterprise/HP99M, India) maintained at $55 \pm 0.5^{\circ} \mathrm{C}$ and the time taken by the animal for the reaction either by licking the paw or jumping or raising the limbs which ever was observe first taken as the end point. Cut off time of $60 \mathrm{~s}$ was followed to avoid any thermal injury to the paws (Prempeh \& Mensah 2008).

\section{- Radiant heat tail-flick method:}

Tail-flick latency was assessed by the analgesiometer (Instruments manufacturing corporation -model/MC-102413, India). The strength of the current passing through the naked nichrome wire was kept constant at $2 \mathrm{~A}$. The distance between heat source and the tail was $1.5 \mathrm{~cm}$ and the application site of the heat on the tail was maintained within $2 \mathrm{~cm}$, measured from the root of the tail.
The time taken by mice to withdraw (flick) the tail was taken as the reaction time. Cut-off reaction time was $30 \mathrm{~s}$ to avoid any tissue injury during the process (Prempeh \& Mensah 2008).

- Tail immersion test:

Mice were held in position in a suitable restrainer with the tail extending out. 3-4 cm area of the tail was marked and immersed in the water bath thermo-statistically maintained at $55 \pm 0.5^{\circ} \mathrm{C}$. The withdrawal time of the tail from hot water was noted as the reaction time or tail flick latency. The maximum cut off time for immersion was $30 \mathrm{~s}$ to avoid the injury of the tissues of tail (D’Amour \& Smith 1941).

\subsubsection{Animal study}

To determine the optimum dose of piperine which was responsible for induction of hyperalgesia, pilot study was carried in following manner.

The mice were randomly divided into six groups containing six mice in each: group I - Non-diabetic control group; group II - Diabetic control group; group III - piperine treated diabetic group; 2.5 $\mathrm{mg} \mathrm{kg}{ }^{-1}$, group IV- piperine treated diabetic group; $5 \mathrm{mg} \mathrm{kg}^{-1}$, group V - piperine treated diabetic group; $10 \mathrm{mg} \mathrm{kg}^{-1}$ and group VI - piperine treated diabetic group; $50 \mathrm{mg} \mathrm{kg}^{-1}$.

Different groups of mice were administered piperine $(2.5,5,10$ and $50 \mathrm{mg} \mathrm{kg}^{-1}$, i.p. respectively), daily for 8 days, starting on day 3 after STZ administration. Nociceptive threshold was noted on day 10 in all groups.

After determination of the optimum dose of piperine, the mice were randomly divided into five groups containing six mice in each: group I - Non-diabetic control group; group II - Diabetic control group; group III - capsaicin treated diabetic group; $1 \mathrm{mg} \mathrm{kg}$ ${ }^{1}$, group IV- piperine treated diabetic group; $5 \mathrm{mg} \mathrm{kg}^{-1}$, and group V - piperine+capsazepine treated diabetic group; $5 \mathrm{mg} \mathrm{kg}^{-1}$, piperine and $15 \mathrm{mg} \mathrm{kg}^{-1}$ capsazepine.

Capsaicin, capsazepine and piperine were administered to their respected groups, daily for 8 days, starting on day 3 after STZ administration. Nociceptive threshold was noted on day 4, 7 and 10 in all groups.

\subsection{Statistics}

All the values were expressed as mean \pm SEM. The data were analyzed by One-way Analysis of Variance (ANOVA) followed by Tukey's multiple range tests. The level of significance was expressed at $\mathrm{P}<0.05$.

\section{Results}

\subsection{Effect of STZ on fasting blood glucose (FBG) level}

Fasting blood glucose level was significantly $(\mathrm{p}<0.05)$ increase in STZ treated mice $(287.21 \pm 7.33 \mathrm{mg} / \mathrm{dl})$ as compare with control mice $(153.58 \pm 2.78 \mathrm{mg} / \mathrm{dl})$.

\subsection{Measurement of nociceptive response}

The diabetic groups showed a significant $(\mathrm{p}<0.05)$ decrease in reaction time, tail flick latency and tail withdrawal latency as compared to control group. In pilot study, nociceptive threshold was decrease significantly $(\mathrm{p}<0.05)$ in piperine $(5,10$ and $50 \mathrm{mg}$ $\mathrm{kg}^{-1}$ ) treated group than model control group (Fig. 3). So, $5 \mathrm{mg} \mathrm{kg}$ 1 piperine was considered to be optimum dose for further study. Reaction time, tail flick latency and tail withdrawal latency was significantly $(\mathrm{p}<0.05)$ decrease in capsaicin as well as piperine received groups as compared to diabetic mice on day 4, 7 and 10 . There was a significant $(\mathrm{p}<0.05)$ increase in reaction time, tail flick latency and tail withdrawal latency, in the animals pre-treated with capsazepine before $2 \mathrm{hr}$ of piperine administration as compared to piperine treated diabetic group on day 4, 7 and 10 (Fig. 4$6)$. 


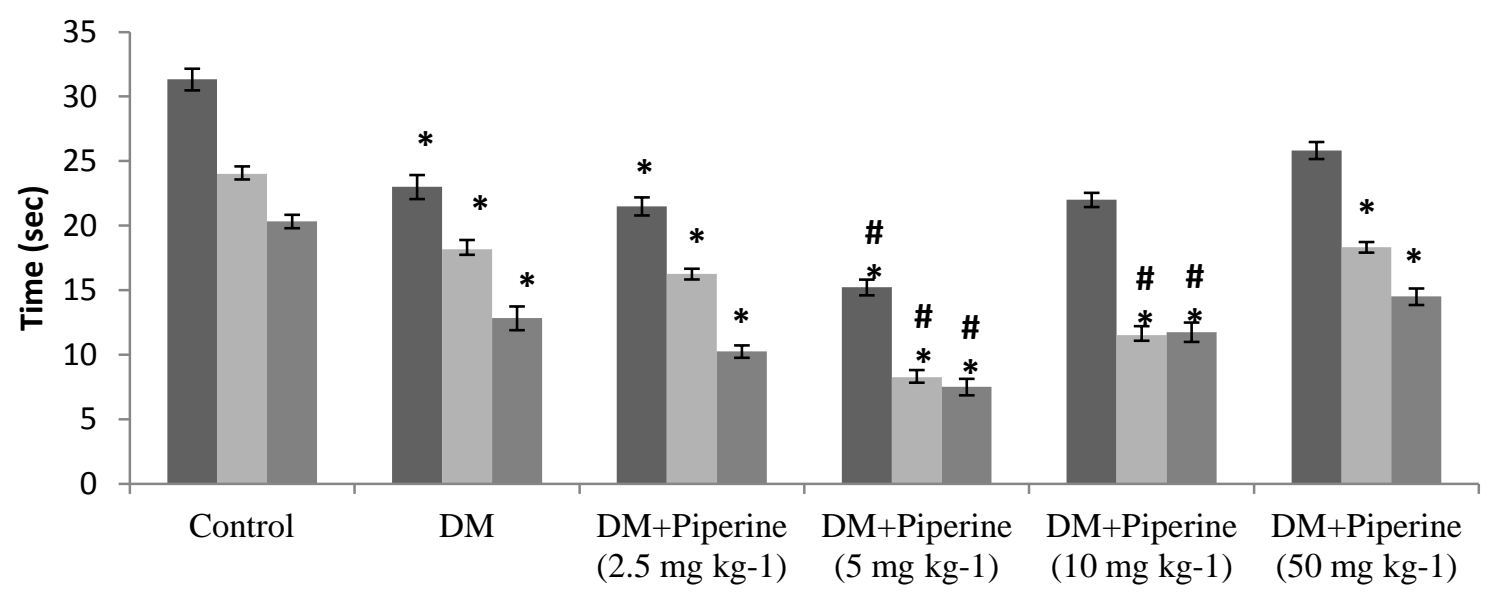

Groups

Fig. 3: Effect of Piperine on Reaction Time, Tail Flick Latency, Tail Withdrawal Latency on Day 10 Reaction time, Tail flick latency, Tail withdrawal latency

All data are Mean \pm SEM ( $n=6$ for each group) $* \mathrm{p}<0.05$ as compared with control group, $\# \mathrm{p}<0.05$ as compared with diabetic group $($ One way ANOVA followed by Tukey's test)

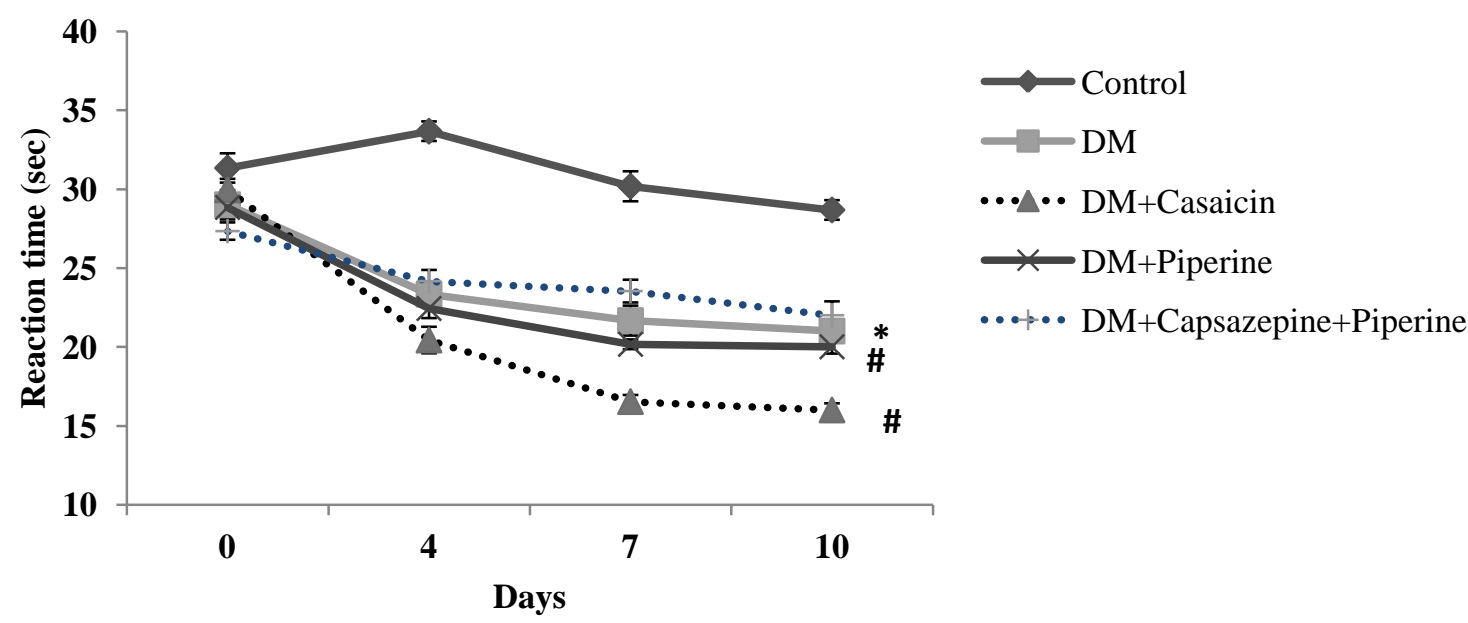

Fig. 4: Effect of Piperine, Capsaicin and Capsazepine on Reaction Time on Day 4, 7 and 10

All data are Mean \pm SEM ( $n=6$ for each group) $* \mathrm{p}<0.05$ as compared with control group, $\# \mathrm{p}<0.05$ as compared with diabetic group (One way ANOVA followed by Tukey's test)

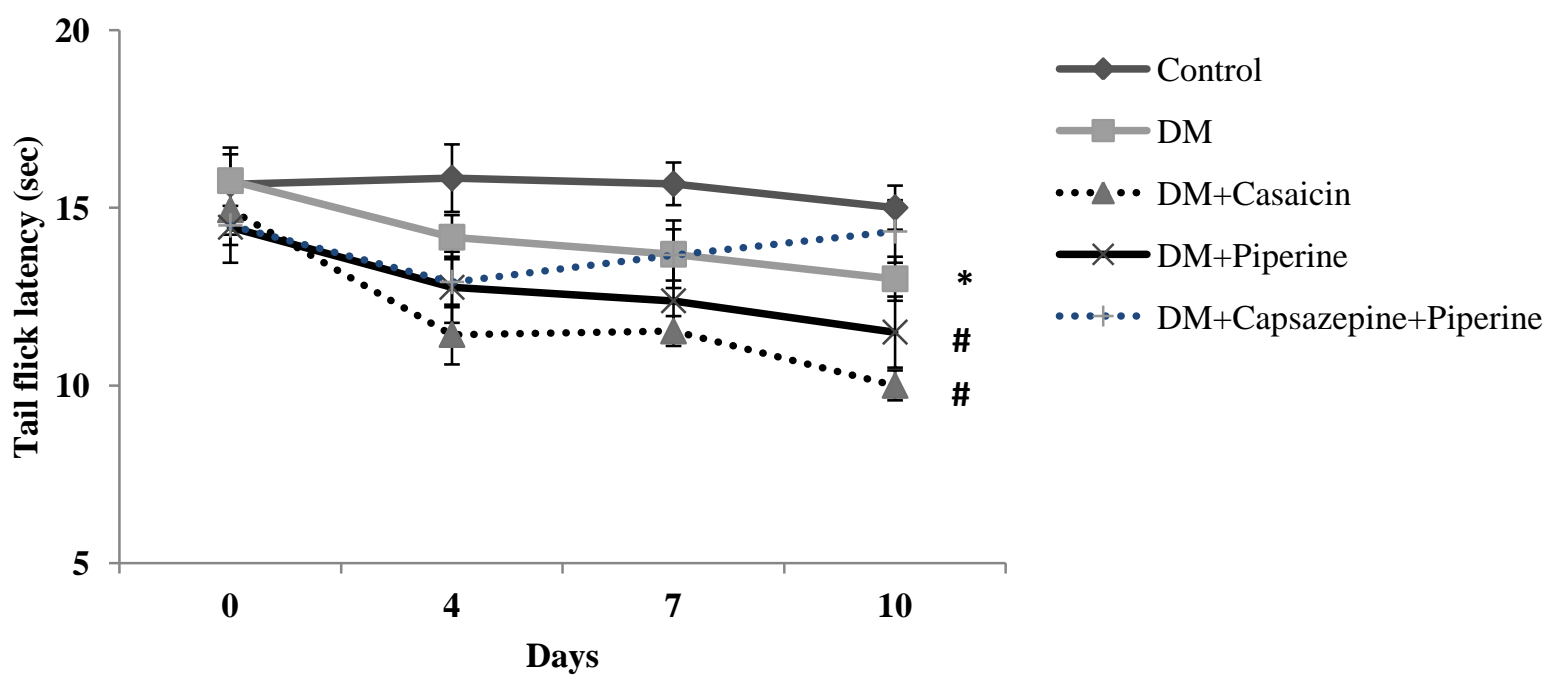

Fig. 5: Effect of Piperine, Capsaicin and Capsazepine on Tail Flick Latency on Day 4, 7 and 10 
All data are Mean \pm SEM ( $\mathrm{n}=6$ for each group) $* \mathrm{p}<0.05$ as compared with control group, $\# \mathrm{p}<0.05$ as compared with diabetic group (One way ANOVA followed by Tukey's test)

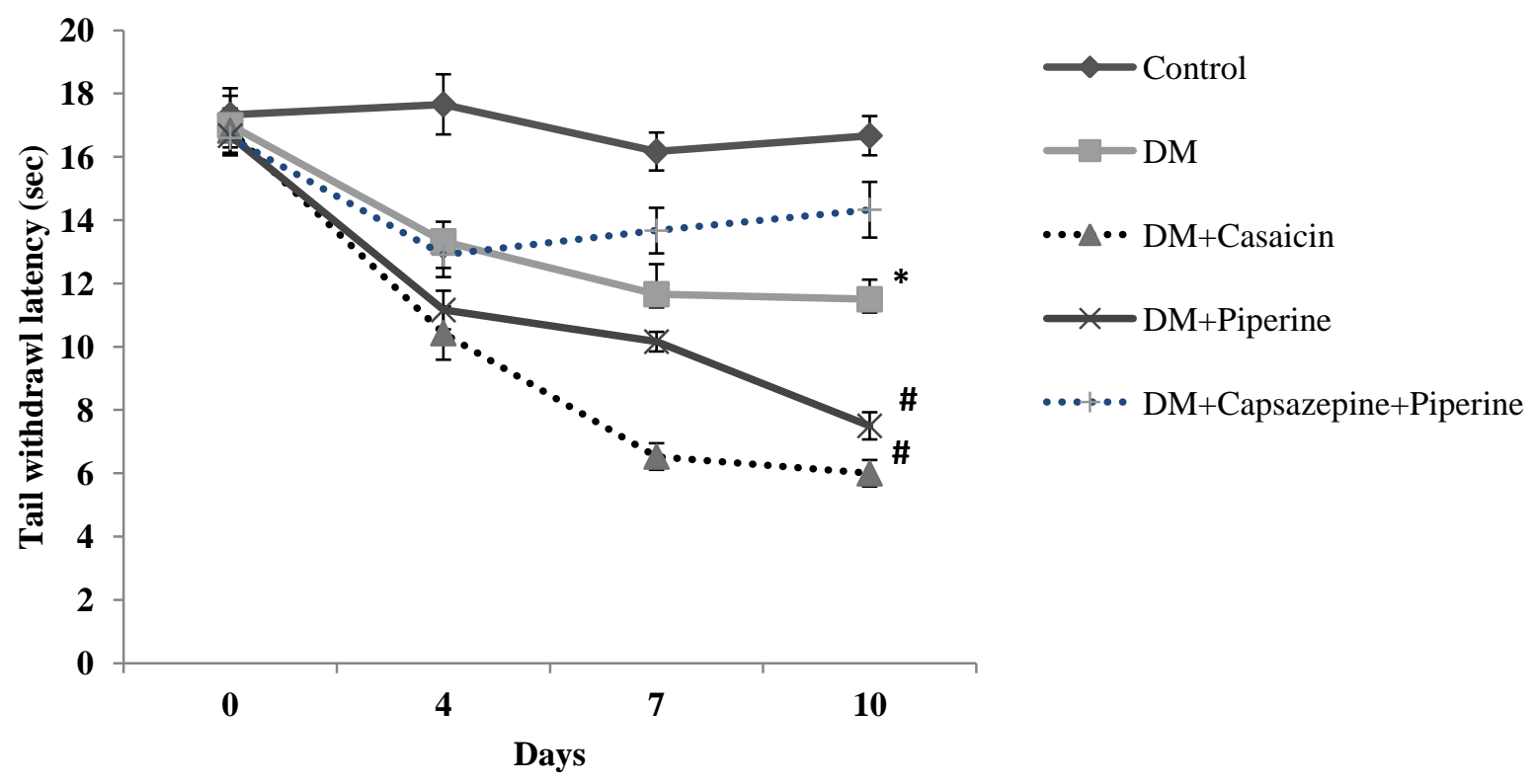

Fig. 6: Effect of Piperine, Capsaicin and Capsazepine on Tail Withdrawal Latency on Day 4, 7 and 10

All data are Mean \pm SEM ( $\mathrm{n}=6$ for each group) $* \mathrm{p}<0.05$ as compared with control group, $\# \mathrm{p}<0.05$ as compared with diabetic group (One way ANOVA followed by Tukey's test).

\section{Discussion}

TRPV1 is a non-selective cation channel of TRP family located on sensory neurons (Patacchini et al. 1990). There are seven subfamily of TRP channel in which TRPV is associated with thermal hyperalgesia (Bichoy \& Pierr 2003). In TRPV, TRPV1 is activated at greater than $43^{\circ} \mathrm{C}$. There is no correlation between heat sensitivity and TRPV 2 in sensory neurons. TRPV 3 and TRPV4 are activated at below the $33^{\circ} \mathrm{C}$. TRPV5 and TRPV6 associated with calcium entry in kidney and intestine respectively (Islam 2011, Venkatachalam \& Montell 2007, Dhaka et al. 2006) TRPV1 is essential for inflammatory thermal hyperalgesia. Hyperalgesia is one of the common complications of diabetes mellitus (Caterina et al. 2000, Davis et al 2000).

The streptozocin-induced diabetic animal model has been put forward as a model of chronic pain with signs of hyperalgesia and allodynia that may reflect signs observed in diabetic humans. STZ-induced hyperglycemia may be involved in development of hyperalgesia following STZ treatment. In streptozotocin-induced diabetic animal model, there is increased expression and function of TRPV1 receptors in neurons of the dorsal root ganglion (DRG) (Lawson et al. 2008). Activation of the nociceptive C-fibres through TRPV1 resulted in opening of cation channel and produce hyperalgesia (Pabbidi et al. 2008). The present study demonstrated that diabetic mice induced by a single injection of STZ could develop significant hyperalgesia. The nociceptive threshold was significantly $(\mathrm{P}<0.05)$ lower in diabetic mice as compared with the control group.

Capsaicin is the pungent ingredient in hot peppers, produces burning pain and hyperalgesia (Simon et al. 2010, LaMotte et al. 1991, LaMotte et al. 1992, Simone \& Ochoa 1991). Capsaicin activates the TRPV1 receptor that is present on Substance P containing nociceptive fibers and thus producing hyperalgesia (Caterina et al. 2000, Simone et al. 1989). Piperine has greater efficacy for TRPV1 receptors and it produce more hyperresposiveness than capsaicin (Tominaga et al. 1998). Capsazepine is a synthetic ana$\log$ of capsaicin. It effectively abolishing capsaicin induced TRPV1 currents in sensory neurons and there by characterized as a first competitive antagonist of capsaicin (Arpad 2005). Capsazepine blocks a significant proportion of capsaicin-evoked hypothermia in rats. Capsazepine also competes for binding with the potent TRPV1 agonist resiniferatoxin in rat spinal cord, sensory neurons and guinea-pig airway membranes (Bevan et al. 1992). In present study, piperine $\left(2.5,5,10\right.$ and $\left.50 \mathrm{mg} \mathrm{kg}^{-1}\right)$ was administration for 10 days in diabetic mice and hyperalgesia was measured in terms of reaction time, tail flick latency and tail withdrawal latency. Piperine at dose of $5 \mathrm{mg} \mathrm{kg}^{-1}$ showed significant $(\mathrm{P}<0.05)$ decrease in reaction time, tail flick latency and tail withdrawal latency than model control group. This suggests that $5 \mathrm{mg}$ $\mathrm{kg}^{-1}$ dose of piperine was optimum dose for hyperalgesic effect in diabetes mellitus. Base on this, $5 \mathrm{mg} \mathrm{kg}^{-1}$ dose of piperine was selected for further study. The hyperalgesic effect of piperine was antagonized by capsazepine; a TRPV1 antagonist indicated the involvement of TRPV1 in piperine induced hyperalgesia in diabetic mice.

\section{Conclusion}

In conclusion, activation of TRPV 1 might be one of the possible mechanisms of piperine induced hyperalgesia (Fig. 7). Further experimental work at molecular level is required for the confirmation of involvement of TRPV1 in piperine induced hyperalgesia in diabetic animals. 


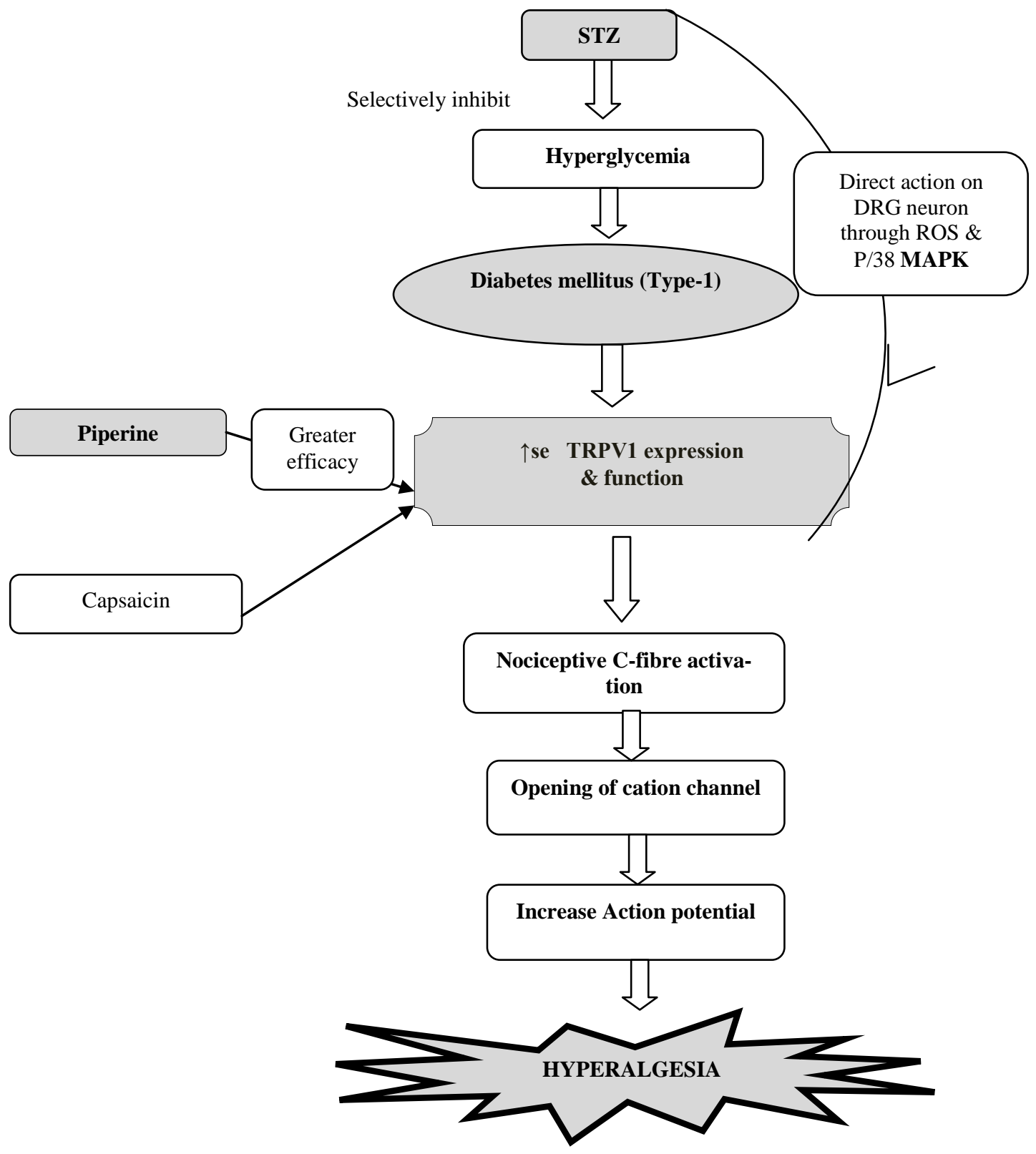

Fig. 7: Role of TRPV1 in Piperine Induce Hyperalgesia

\section{References}

[1] Arpad S (2005) Piperine: Researchers discover new flavor in an ancient spice. Trends in Pharmacological Sciences 26(9), 123-126.

[2] Bevan S, Hothi S, Hughes G, James IF, Rang HP \& Shah K (1992) Capsazepine: a competitive antagonist of the sensory neurone excitant capsaicin. British Journal of Pharmacology 107, 544-552. http://dx.doi.org/10.1111/j.1476-5381.1992.tb12781.x.

[3] Bichoy H \& Pierr S (2003) Kinin B1 receptor antagonists inhibit diabetes-induced hyperalgesia in mice. Neuropeptides 37, 36-44 http://dx.doi.org/10.1016/S0143-4179 (02)00148-8.

[4] Caterina MJ, Leffler a \& Malmberg AB (2000) Impaired nociception and pain sensation in mice lacking the capsaicin receptor. Science 288 306-313. http://dx.doi.org/10.1126/science.288.5464.306.

[5] Caterina MJ, Schumacher MA, Timinaga M, Rosen TA, Levine JD \& Julius D (1997) The capsaicin receptor:a heat-activated ion channel in the pain pathway. Nature 389, 816-824. http://dx.doi.org/10.1038/39807.

[6] Cesare P, Moriondo A, Vellani V \& McNaughton PA (1999) Ion channels gated by heat. Proceedings of the National Academy of Sciences of the United States of America 96, 7658-7663. http://dx.doi.org/10.1073/pnas.96.14.7658.

[7] Chakir M \& Plante GE (1996) endothelial dysfunction in diabetes mellitus. Prostaglandins Leukotrienes and Essential Fatty Acids 54, 45-51. http://dx.doi.org/10.1016/S0952-3278 (96)90080-0.
[8] D'Amour FE \& Smith DL (1941) A method for determining loss of pain sensation. Journal of Pharmacology and Experimental Therapeutics 72, 74-79.

[9] Davis JB, Gray J, Gunthorpe MJ, Hatcher JP, Davey PT, Overend P, Harries MH, Latcham J, Clapham C, Atkinson K, Hughes SA, Rance K, Grau E, Harper AJ, Pugh PL, Rogers DC, Bingham S, Randall A \& Sheardown SA (2000) Vanilloid receptor-1 is essential for inflammatory thermal hyperalgesia. Nature 405, 183-187. http://dx.doi.org/10.1038/35012076.

[10]Dhaka A, Viswanath V \& Patapoutian A (2006) TRP ion channels and temperature sensation. Annual Review of Neuroscience 29, 135-161. http://dx.doi.org/10.1146/annurev.neuro.29.051605.112958.

[11]Hudson LJ, Bevan S, Wotherspoon G, Gentry C, Fox A \& Winter J (2001) VR1 protein expression increases in undamaged DRG neurons after partial nerve injury. Europian Journal of Neuroscience 13: 2105 2114. http://dx.doi.org/10.1046/j.0953-816x.2001.01591.x.

[12]Islam MS (2011) Transient Receptor Potential Channels. Advance in Experimental Medicine and Biology 30, 700.

[13]LaMotte RH, Lundberg LE \& Torebjork HE (1992) Pain, hyperalgesia and activity in nociceptive $\mathrm{C}$ units in humans after intradermal injection of capsaicin. J Physiology-Paris 448, 749-764.

[14]LaMotte RH, Shain CN, Simone DA \& Tsai EF (1991) Neurogenic hyperalgesia:psychophysical studies of underlying mechanisms. Journal of Neurophysiology 66, 190-211.

[15]Lawson JJ, McIlwrath SL \& Woodbury CJ (2008) TRPV1 unlike TRPV2 is restricted to a subset of mechanically insensitive cutaneous nociceptors responding to heat. Journal of Pain 9, 298-308. http://dx.doi.org/10.1016/j.jpain.2007.12.001. 
[16]McNamara FN, Randall A \& Gunthorpe MJ (2005) Effects of piperine, the pungent component of black pepper, at the human vanilloid receptor (TRPV1). British Journal of Pharmacoly 144,781-790. http://dx.doi.org/10.1038/sj.bjp.0706040.

[17]Pabbidi RM, Cao DS, Parihar A, Pauza ME \& Premkumar LS (2008) direct role of streptozotocin in inducing thermal hyperalgesia by enhanced expression of transient receptor potential vanilloid 1 in sensory neurons. Molecular Pharmacology 73, 995-1004. http://dx.doi.org/10.1124/mol.107.041707.

[18]Patacchini R, Maggi CA \& Meli A (1990) Capsaicin-like activity of some natural pungent substances on peripheral endings of visceral primary afferents. Naunyn Schmiedebergs Arch Pharmacol. 342, 72 77. http://dx.doi.org/10.1007/BF00178975.

[19]Pingle SC, Matta JA \& Ahern GP (2007) Capsaicin receptor: TRPV1 a promiscuous TRP channel. Handbook of Experimenal Pharmacology 179, 155-171. http://dx.doi.org/10.1007/978-3-540-34891-7_9.

[20]Prempeh AB \& Mensah AJ (2008) Analgesic activity of crude aqueous extract of the root bark of Zanthoxylum Xanthoxyloides. Ghana Medical Journal 42, 79-84.

[21]Rashid MH, Inoue M, Bakoshi S \& Ueda H (2003a) Increased expression of vanilloid receptor 1 on myelinated primary afferent neurons contributes to the antihyperalgesic effect of capsaicin cream in diabetic neuropathic pain in mice. Journal of Pharmacology and Experimental Therapeutics 306, 709-717. http://dx.doi.org/10.1124/jpet.103.050948.

[22] Rashid MH, Inoue M, Kondo S, Kawashima T, Bakoshi S \& Ueda H (2003b) Novel expression of vanilloid receptor 1 on capsaicininsensitive fibers accounts for the analgesic effect of capsaicin cream in neuropathic pain. Journal of Pharmacology and Experimental Therapeutics 304, 940-948. http://dx.doi.org/10.1124/jpet.102.046250.

[23]Simon B, Xue JL, Chun K \& Michael WS (2010) Peripheral nerve injury and TRPV1-expressing primary afferent C-fibers cause opening of the blood-brain barrier. Molecular Pain 6, 74. http://dx.doi.org/10.1186/1744-8069-6-74.

[24]Simone DA \& Ochoa J (1991) early and late effects of prolonged topical capsaicin on cutaneous sensibility and neurogenic vasodilatation in humans. Pain 47, 285-294. http://dx.doi.org/10.1016/03043959 (91)90217-L.

[25]Simone DA, Baumann TK \& LaMotte RH (1989) Dose-dependent pain and mechanical hyperalgesia in humans after intradermal injection of capsaicin. Pain 38, 99-107. http://dx.doi.org/10.1016/03043959 (89)90079-1.

[26]26. Spruce MC, Potter J \& Coppini DV (2003) the pathogenesis and management of painful diabetic neuropathy: a review. Diabetic Medicine 20, 88-98. http://dx.doi.org/10.1046/j.1464-5491.2003.00852.x.

[27]Szallasi A \& Blumberg PM (1999) Vanilloid (capsaicin) receptors and mechanisms. Pharmacological Reviews 51, 159-212.

[28]Szolcsanyi J (1983) Tetrodotoxin-resistant non-cholinergic neurogenic contraction evoked by capsaicinoids and piperine on the guinea-pig $\begin{array}{llll}\text { trachea. Neuroscience } & \text { Letter } & \text { 82, } & \end{array}$ http://dx.doi.org/10.1016/0304-3940 (83)90426-3.

[29]Tominaga M, Caterina MJ, Malmberg AB, Rosen TA, Gilbert H Skinner K, Raumann BE, Basbaum AI, Julius D (1998) The cloned capsaicin receptor integrates multiple pain-producing stimuli. Neuron 21, 531-543. http://dx.doi.org/10.1016/S0896-6273 (00)80564-4.

[30]Trinder P (1996) Determination of glucose in blood using glucose oxidase with an alternative oxygen acceptor. Annals of Clinical Biochemistry 6, 24. http://dx.doi.org/10.1177/000456326900600108.

[31]Venkatachalam K \& Montell C (2007) TRP channels. Annual Review of Biochemistry 76, 387-417. http://dx.doi.org/10.1146/annurev.biochem.75.103004.142819.

[32] Voets T, Droogmans G, Wissenbach U, Janssens A, Flockerzi V \& Nilius B (2004) The principle of temperature-dependent gating in cold- and heat-sensitive TRP channels. Nature 430, 748-754. http://dx.doi.org/10.1038/nature02732. 